\title{
Pengaruh Bone Marrow Mesenchymal Stem Cells Terhadap Sekresi VEGF pada Penyembuhan Luka Bakar Tikus
}

\author{
Gusti Revilla
}

\begin{abstract}
Abstrak
Penanganan luka bakar telah dilakukan dengan berbagai cara, tetapi belum memberikan hasil yang memuaskan, sehingga diperlukan pengobatan dengan menggunakan stem sel. Pemberian Mesenchymal Stem Cells (MSC) untuk penyembuhan luka diketahui dapat mempercepat pembentukan jaringan granulasi, namun mekanismenya belum banyak diketahui. Tujuan penelitian ini adalah melihat pengaruh pemberian MSCs terhadap sekresi VEGF pada proses penyembuhan luka bakar tikus. Penelitian bersifat eksperimental dengan desain the post test only control terhadap 12 ekor tikus Wistar, yang dibagi atas kelompok kontrol (PBS) dan perlakuan Bone Marrow Mesenchymal Stem Cells (BM-MSCs). Stem sel diberikan subkutan dosis $2 \times 106 \mathrm{sel} / \mathrm{ml}$. Sebelum diperlakukan, tikus dianestesi dengan menggunakan xylazine dan ketamin kemudian tikus dibuat luka bakar di bagian dorsal (punggung) dengan derajat full thickness. Pada hari ke 3 dan 7 diambil darah untuk mengukur kadar VEGF dengan metode Elisa. Hasil penelitian dianalisis dengan uji-t. Sekresi kadar VEGF hari ke 3 dan ke 7 pada kelompok diberi BM-MSCs lebih rendah yaitu $12.875 \mathrm{pg} / \mathrm{ml}$ dan $23.917 \mathrm{pg} / \mathrm{ml}$ dibandingkan dengan kelompok kontrol yaitu $61.667 \mathrm{pg} / \mathrm{ml}$ dan 200.042 $\mathrm{pg} / \mathrm{ml}$. Terdapat perbedaan yang bermakna diantara ke dua kelompok dengan $p=0.012$ dan $p=0.038$. Simpulan penelitian ini menunjukkan pemberian stem sel BM-MSCs mampu mempengaruhi kadar VEGF yang mungkin BMMSCs berdiferensiasi menjadi sel-sel yang berperan dalam angiogenesis, ini mempercepat pembentukan jaringan granulasi.
\end{abstract}

Kata kunci: BM-MSCs, VEGF, penyembuhan luka bakar

\begin{abstract}
Treatment for burns have been carried out in various ways, but have not provided satisfactory results, so that using stem cells is necessary. Administering Bone Marrow Mesenchymal Stem Cells (BM-MSCs) for healing, are by accelerating the formation of granulation tissue, however the effectiveness of the provision of is still under exploration. The objective of this study was to determine the effect of the administration of stem cells BM-MSCs on VEGF secretion on burn healing process in rats. This research was an experimental research with design the post-test only control, using 12 Wistar rats, divided into 2 groups: control (PBS), treatment (BM-MSCs), stem-cells subcutaneously administered dose of $2 \times 106$ cells / ml. Before that the treated rats anesthetized using xylazine and ketamine then burns are made on the dorsal with full thickness degrees. On day 3 and 7, blood were obtained to measure levels of VEGF was measured by ELISA. The results were analyzed by t-test. Levels of VEGF in day 3 and day 7 in the group given BM-MSC were dereased $12.875 \mathrm{pg} / \mathrm{ml}$ dan $23.917 \mathrm{pg} / \mathrm{ml}$ compared to the control group $61.667 \mathrm{pg} / \mathrm{ml}$ and $200.042 \mathrm{pg} / \mathrm{ml}$ and showed significant differences $p=0.012$ and $p=0.038$. The conclusion of this study is the administration of BM-MSCs were the influence levels of VEGF which has into differentiate to cells that contribute to angiogenesis was can to granulation tissue.
\end{abstract}

Keywords: BM-MSC, VEGF, Wound healing burns

Affiliasi penulis: Bagian Anatomi Fakultas Kedokteran Universtas Andalas Padang
Korespondensi: Gusti Revilla, Email: Gustirevillaelok@yahoo.com Telp: 081363269604A 


\section{PENDAHULUAN}

Luka bakar merupakan salah satu masalah kesehatan yang serius bagi masyarakat negara berkembang karena luka bakar dapat menimbulkan kerusakan fisik sampai dengan kematian. Luka bakar dapat disebabkan oleh suhu panas (thermal), kimia, elektrik dan radiasi. Kerusakan yang terjadi akibat luka bakar tergantung pada letak, kedalaman dan luas dari luka bakar ${ }^{1}$

Kedalaman luka bakar tergantung pada tingginya suhu dan lamanya terpapar dengan suhu yang panas. Berdasarkan kedalamannya luka bakar dibagi menjadi tiga bagian yaitu derajat satu (superficial), derajat dua (partial) dan derajat tiga (full thickness) yang mengenai seluruh lapisan epidermis dan dermis. Keadaan ini memerlukan penanganan yang tepat dan baik, sehingga mempercepat penyembuhan luka. ${ }^{2,3}$

Penyembuhan luka bakar merupakan suatu proses yang komplek melibatkan beberapa tahap yang saling berkaitan yaitu inflamasi, proliferasi (jaringan granulasi, reepitelisasi, pembentukan matriks ektraseluler) dan remodelling. Ke tiga fase penyembuhan luka ini akan melibatkan interaksi dari beberapa mediator, sel dan protein matrix extracellular. $^{4}$

Penanganan luka bakar yang dalam telah dilakukan dengan berbagai cara diantaranya adalah pencangkokan kulit, pemberian faktor pertumbuhan, namun belum memberikan hasil yang memuaskan, karena perbaikan kulit belum memberikan hasil yang memuaskan. Saat ini, perhatian para peneliti sangat terfokus pada penggunaan stem cell atau sel punca untuk pengobatan berbagai penyakit di antaranya luka bakar. $^{5}$

Stem sel dapat berasal dari sumsum tulang, jaringan lemak, Peripheral Blood Mononuclear Cells (PBMCs) dan sel darah tali pusat. Stem sel pada sumsum tulang dapat berupa stem sel hematopoetik dan Mesenchimal Stem Cells (MSCs). Bila terjadi kerusakan maka stem sel endogen PBMC dan MSC berkontribusi dalam penyembuhan melalui efek parakrin dan bertransdiferensiasi, namun jika kerusakan terlalu besar maka stem sel endogen tidak mampu memperbaiki kerusakan maka diperlukan pemberian stem sel eksogen. ${ }^{5}$
Bone Marrow Mesenchymal Stem Cells (BM-

MSCs) merupakan stem sel yang bersifat multipotent progenitor dan dapat berdiferensiasi menjadi kondrosit, osteoblast, adiposit, miosit, fibroblast, myofibroblast sel epitel, endotel dan sel neuron. ${ }^{6,7}$ BMMSCs mempunyai potensi yang kuat dalam regenerasi jaringan kulit, ${ }^{8,9}$ namun penelitian pemberian BM-MSCs untuk luka kulit efektif atau tidak masih dalam tahap penelitian. ${ }^{10}$

Beberapa penelitian BM-MSCs yang telah dilakukan pada luka insisi dengan pemberian injeksi diketahui bahwa BM-MSCs dapat mempercepat penutupan luka dengan kualitas penyembuhan yang baik, sehingga pemberian BM-MSCs sangat dibutuhkan dalam perbaikan luka kulit.$^{11}$ Penelitian BM-MSCs pada angiogenesis diketahui dapat meningkatkan densitas dari kapiler dan ini dapat dihubungkan dengan pembentukan pembuluh darah baru. Pembentukan pembuluh darah baru dipengaruhi oleh kemampuan dari MSC untuk berdiferensiasi menjadi sel endotel, mengeluarkan faktor solubel diantaranya faktor angiogenik, ${ }^{12}$ dan pembentukan otot polos pembuluh yang berperan dalam menyatukan endotel dinding pembuluh. ${ }^{13}$ Mesenchimal stem cells juga dapat meningkatkan proliferasi sel endotel dan permeabilitas pembuluh darah. ${ }^{14}$ Proliferasi sel endotel dan permeabilitas dari pembuluh darah akan dipengaruhi oleh factor angigenik diantaranya vascular endothelial growth factor (VEGF). VEGF merupakan glikoprotein yang berperan penting dalam vasculogenesis selama embriogenesis dan pembentukan pembuluh darah baru (angiogenesis) pada penyembuhan luka dan fungsi reproduksi wanita dewasa. Pada penyembuhan luka VEGF berperan penting dalam angiogenesis dengan menstimulasi proliferasi, migrasi dan organisasi sel endotel untuk membentuk tubulus pembuluh. ${ }^{15}$ Untuk itu dilakukan penelitian pengaruh BM-MSCs terhadap sekresi kadar VEGF pada tikus luka bakar.

\section{METODE}

\section{Stem Sel MSC Bersal Dari Sumsum Tulang Tikus}

MSC yang digunakan pada penelitian ini adalah yang sudah ada dilaboratorium ITD C FK Unair Surabaya. Sebelum digunakan MSC dalam tabung 
petridish yang monolayer akan dipisahkan untuk dihitung jumlah sel yang akan digunakan dalam penelitian. Penggunaan MSC untuk 1 ekor tikus dalam penelitian ini adalah $2 \times 10^{6} \mathrm{sel} / \mathrm{ml}$

\section{Persiapan hewan coba (tikus) untuk luka bakar}

Pembuatan Luka Bakar pada Tikus (metode Paramonov dan Cheboterev cit Shuid et al., 2008) ${ }^{16}$. Tikus diberi anestesi dengan xylazin dan ketamin (perbandingan 1: 1), kemudian dicukur bulu bagian punggung. Untuk membuat luka bakar full thickness plate dipanaskan dalam air mendidih selama 30 menit dan ditempelkan pada punggung tikus selama 20 detik. Setelah itu diinjeksi PBS untuk kelompok kontrol dan PBMC untuk kelompok perlakuan, kemudian luka ditutup dengan tegaderm film dan kasa elastomult haft. Tikus juga diberi analgesik yaitu antalgin injeksi. Pada hari ke 3 dan 7 diambil darah melewati intrakardial untuk mengukur kadar faktor pertumbuhan VEGF dengan metode elisa dengan menggunakan Kit VEGF (R\&D system) dan pada hari ke 14 diambil jaringan kulit luka bakar untuk melihat ekspresi dari kolagen keluaran (R\&D system) dengan metode imunohistokimia kemudian tikus dikorban dengan cara pemberian kloroform.

\section{Pemeriksaan faktor pertumbuhan VEGF dengan metode Elisa}

Darah yang sudah diambil, kemudian disentrifus untuk mendapatkan serum. Ambil plat well masukan $50 \mu \mathrm{l}$ assay diluent kesemua well (blanko, standart, dan sampel), kemudian masukan $50 \mu \mathrm{l}$ larutan standart, kontrol dan sampel. Plat Well diletakkan di atas sekher digerakkan dengan kecepatan $50 \mathrm{rpm}$ selama $3-5$ menit, setelah itu plat well ditutup dengan plastik adhesive, dan inkubasi dalam suhu ruang selama 2 jam. Larutan hasil inkubasi pada well disedot dengan menggunakan pipet multichannel dan plat well dicuci dengan washing buffer $300 \mu \mathrm{l} /$ well, kegiatan ini dilakukan sampai 4 kali. Tambahkan $100 \mu \mathrm{l}$ enzim conjugate kesemua well kecuali blanko (diisi dengan washing buffer $100 \mu \mathrm{l}$ ), kemudian tutup dengan plastik adhesive film seterusnya diinkubasi selama 2 jam dalam suhu ruang dan setelah inkubasi cairan conjugate dibuang. Tambahkan $100 \mu$ l substrat solution kemasing-masing well, inkubasi selama 30 menit pada suhu ruang dalam kondisi gelap. Tambahkan stop solution sebanyak $100 \mu \mathrm{l}$ kemasing-masing well dan masukan plat well ke alat Elisa microplate reader pada panjang gelombang $450 \mathrm{~nm}$. Hasil pengukuran tersebut keluar dalam bentuk absorban dan konsentrasi dan hasil ukuran yang digunakan adalah konsentrasi.

Penelitian ini sudah dilakukan etika clearance dan sudah mendapat persetujuan oleh the Comittee of the Research Ethics of the Faculty of Medicine, Andalas University untuk dilaksanakan penelitian.

Analisis pengaruh stem sel MSC terhadap kadar faktor pertumbuhan VEGF dilakukan analisis dengan uji oneway Anova dengan uji lanjut Tukey.

\section{HASIL}

Sekresi kadar faktor pertumbuhan VEGF pada serum luka bakar full thickness tikus, dihitung pada hari ke 3 dan ke 7. Rata-rata kadar sekresi faktor pertumbuhan VEGF dapat dilihat pada Tabel 1 dan Gambar 1.

Tabel 1. Rerata kadar sekresi faktor pertumbuhan VEGF serum luka bakar full thickness tikus pada hari ke 3 dan 7

\begin{tabular}{ccccc}
\hline KIpk & \multicolumn{4}{c}{ Kadar Rata-rata VEGF (pg/ml) hari ke } \\
& $\mathbf{3}$ & $\mathbf{7}$ & $\mathbf{p}$ \\
\hline $\mathrm{K}$ & $61.667 \pm$ & 0.012 & $200.042 \pm$ & 0.03 \\
& 39.751 & 19.812 & 8 \\
$\mathrm{PI}$ & $12.875 \pm$ & $23.917 \pm$ & \\
& 10.861 & 11.988 & \\
\hline
\end{tabular}

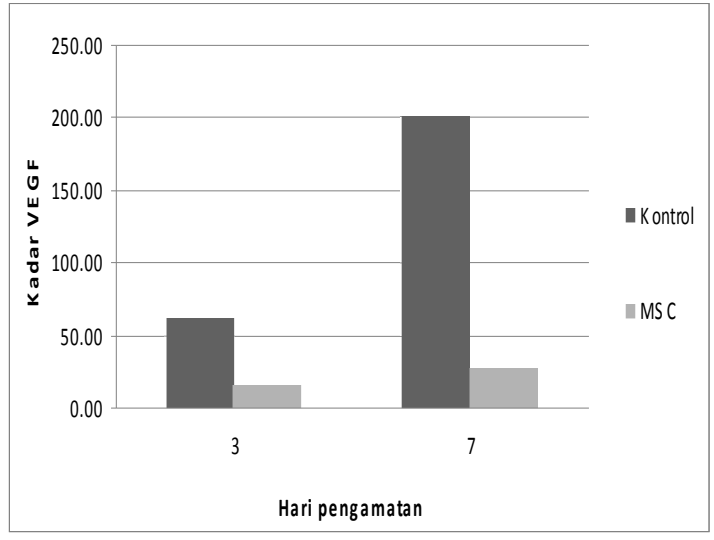

Gambar 1. Grafik rerata kadar sekresi faktor pertumbuhan VEGF pada kelompok kontrol dan kelompok MSC pada hari ke 3 dan 7 
Berdasarkan Tabel 1 dan Gambar 1 grafik rerata sekresi VEGF dapat dilihat bahwa pada hari ke 3 dan 7, rerata kadar VEGF kelompok kontrol lebih tinggi dari kelompok MSC. Secara statistik rerata kadar VEGF ini menunjukkan perbedaan yang bermakna pada $p=0.012$ dan $p=0.038$.

\section{PEMBAHASAN}

VEGF merupakan faktor pertumbuhan yang telah dihasilkan pada awal luka setelah terjadinya agregasi platelet. VEGF berperan dalam migrasi, proliferasi dari sel endotel sehingga akan mempengaruhi proses angiogenesis.

Hasil analisis data menunjukkan bahwa kadar VEGF pada hari ke 3 dan ke 7 setelah diberi BMMSCs, lebih rendah dibandingkan dengan kelompok kontrol. Penurunan kadar VEGF ini secara statistik menunjukkan perbedaan yang bermakna. Penurunan kadar VEGF setelah diberi BM-MSCs, mungkin disebabkan karena stem sel BM-MSCs setelah berada pada jaringan luka mengalami diferensiasi. Hasil ini juga sesuai dengan hasil penelitian lain bahwa stem sel ini akan berakumulasi di sekitar luka dan lingkungan mikro (adanya sitokin dan faktor pertumbuhan) yang ada di sekitar luka akan mempengaruhi BM-MSCs, sehingga terjadi diferensiasi stem sel menjadi endotel dan sel kulit lainnya. ${ }^{10}$ Pada penelitian ini mungkin juga terjadi diferensiasi BM-MSCs menjadi sel endotel dan keratinosit, keadaan ini terlihat dengan penyembuhan luka yang lebih cepat dibandingkan kelompok kontrol.

Percepatan penyembuhan luka bakar pada tikus yang diberi BM-MSCs juga sejalan dengan yang ditemukan oleh peneliti lain yaitu BM-MSCs akan mempercepat penyembuhan luka dengan mengawali angiogenesis, 10,11 meningkatkan reepitelisasi dan pembentukan sel diantaranya keratinosit, ${ }^{11}$ meningkatkan proliferasi dan migrasi fibroblast. ${ }^{17}$ Peran BM-MSCs dalam mengawali angiogenesis di antaranya menghasilkan faktor proangiogenik dan antiangiogenik yang mengakibatkan angiogenesis dapat terjadi dengan baik. Faktor proangiogenik ini akan menstimulasi proliferasi, migrasi sel endotel dan mengatur sel untuk membentuk tabung pembuluh. ${ }^{11}$

Dalam angiogenesis banyak faktor angiogenik yang berperan di antaranya FGF, angiotensin dan
TGF- $\beta$. Pada penelitian ini kadar VEGF setelah diberi BM-MSCs menurun dibandingkan dengan kontrol. Ini mungkin disebabkan karena BM-MSCs mampu meningkatkan faktor angiogenik lainnya. Untuk itu perlu penelitian lebih lanjut untuk menguji faktor angiogenik lain yang berperan dalam angiogenesis. Kadar VEGF yang tinggi juga dapat mempunyai efek yang tidak baik yaitu dapat menimbulkan jaringan parut. $^{18}$

\section{SIMPULAN}

Pemberian BM-MSCs mampu mempercepat penyembuhan luka bakar pada tikus, walaupun menurunkan kadar VEGF dan mungkin stem sel ini dapat mempengaruhi faktor angiogenik lainnya.

\section{DAFTAR PUSTAKA}

1. Evers $L H$, Bhavsar $D$, Mailander $P$. The biology of burn injury. Experimental Dermatology. 2010;19: 777-83.

2. Syamsuhidayat R. Buku ajar ilmu bedah. Edisi Revisi. Jakarta: EGC; 1997.

3. Vern AK, Latense BA. Specimen collection and analysis burn wound. Methods in molecular medicine wound healing. Edited by Luisa $D$ and Aime, L.B. Vol. 78. N.J: Human Press Inc. Totowa; 2001.

4. Kumar S, Peng FW, David JL. What is new in wound healing. Turk J Med Sci. 2004;34:147-60.

5. Metcalfe $A D$, Ferguson MWJ. Tissue engineering of replacement skin: the crossroads of biomaterials, wound healing, embryonic development, stem cells and regeneration. Journal Royal Society interface. 2007;4: 413-37.

6. Pittenger M F, Mackay AM, Beck SC, Jaiswal RK, Douglas R, Mosca JD, Moorman MA, Simonetti DW, Craig S, Marshak DR. Multilineage potential of adult human mesenchymal stem cells. Science. 1999; 284:143-7.

7. Liu ZJ, Zhuge Y, Velazquez O.C. Trafficking and differentiation of mesenchymal stem cells. Journal of Cellular Biochemistry. 2009;106:984-91.

8. Semon JA, Nagy LH, Llamas CB, Tucker HA, Lee $\mathrm{R}, \mathrm{H}$ Darwin J. Integrin expression and integrin-mediated adhesion in vitro of human multipotent stromal cells (MSCs) to endothelial 
cells from various blood vessels. Prockop Cell Tissue Res. 2010; 341:147-58.

9. Jeon YK, Jang YH, Yoo DR, Kim SN, Lee SK, Nam MJ. Mesenchymal stem cells' interaction with skin: Wound-healing effect on fibroblast cells and skin tissue. Wound Rep Reg. 2010;18:655-61.

10. Sasaki M, Abe R, Fujita Y, Ando S, Inokuma D, Hiroshi S. Mesenchymal stem cells are recruited into skin cell type repair by transdifferentiation into multiple wounded skin and contribute to wound. J Immunol. 2008;180:2581-7.

11. Wu Y, Chen L, Scott PG, Tredget EE. Mesenchymal stem cells enhance wound healing through differentiation and angiogenesis. Stem CellS. 2007;25:2648-59.

12. Oswald J, Boxberger S, Jorgensen B, Feldmann S, Ehninger $\mathrm{G}$, et al. Mesenchymal stem cells can be differentiated into endothelial cells in vitro. Stem Cells. 2007;22:377-84.

13. Al-Khaldi A, Al-Sabti H, Galipeau J, Lachapelle K. Therapeutic angiogenesis using autologous bone marrow stromal cells: improved blood flow in a chronic limb ischemia model. Ann Thorac Surg 2003;75:204-9.

14. Salvolini E, Lucarini G, Zizzi A, Orciani M, Di Benedetto G, Di Primio R. Human skin-derived mesenchymal stem cells as a source of VEGF and nitric oxide. Arch Dermatol Res. 2010; 302:367-74.

15. Ferrara N. Vascular endothelial growth factor. Arterioscler Thromb Vasc Biol. 2009; 29:789-91.

16. Shuid AN, Mohamad SA, Ahmad AY. The effects of Carica papaya Linn latex on the healing of burn wound in rats. Jurnal Sains Kesihatan Malaysia. 2005;3(2):39-47.

17. Dulchavsky D, Gao X, Liu YB, Deeb D, Arbab AS, McIntosh K, Dulchavsky SA and Gautam S C. Bone marrow-derived stromal cells (BMSCs) interact with fibroblasts in accelerating wound healing. J Invest Surg. 2008;21(5):270-9.

18. Van der Veer WM, Bloemen MC, Ulrico MM, Molema G, van Zuijlen PP, Middelkoop E and Niessen FB. Potential cellular and molecular causes of hypertrophic scar formation. Burns. 2009;35:15-29. 